\title{
¡De película! \\ Hollywood y su impacto en Chile 1910-1950*
}

Fernando Purcell

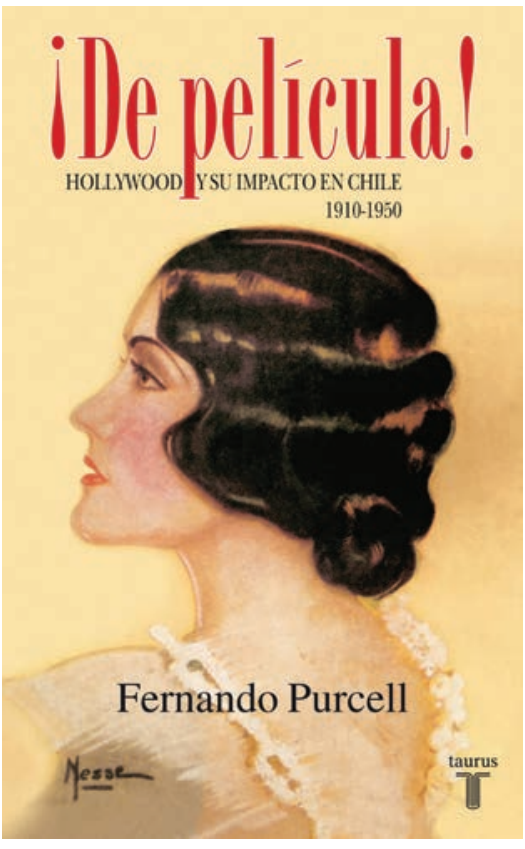

Marcela SaA-Espinoza*

1. Cine y norteamericanización de la cultura chilena

Durante la primera mitad del siglo XX, los(as) chilenos(as) se vieron rodeados(as) de una creciente cantidad de imágenes, sonidos

** Correo electrónico: marcelasaae@gmail.com 
y evocaciones del mundo moderno que moldeaban las nuevas necesidades del país. El cine, en este escenario, condujo didáctica e intencionadamente los alcances de una narración modernizadora que se desplegaba mundialmente, encabezada principalmente por los Estados Unidos. A partir de este contexto, y haciendo uso de crónicas de revistas, noticias y diversas fuentes historiográficas, Fernando Purcell elabora una trama que revela la significativa acción del séptimo arte en la vehiculización del relato moderno -y norteamericano- en Chile.

Con la instalación de la cultura de masas en el país, la industria cultural tuvo un papel trascendental en la introducción de ideas modernas en la sociedad chilena. Es fácil reconocer en las primeras tres décadas del 1900 un conjunto de prácticas entre los(as) chilenos(as), tales como bailes, salidas entre jóvenes sin supervisión adulta, obtención de estéticas corporales diferentes por parte de las mujeres, etc., lo que estuvo acompañado por la incorporación de una serie de productos como revistas especializadas en cine, moda, familia y juventud, con lo cual se fue configurando una nueva subjetividad moderna. En esta dirección, el cine fue otro de los dispositivos que se desplegó para entretener a la población, pero también para implantar y posicionar ideas que conformaron sus imaginarios y sus aspiraciones. El libro reseñado indaga precisamente en aquellas prácticas y productos que permitieron la consolidación y la hegemonía del cine hollywoodense en Chile, así como su apropiación por parte de los(as) chilenos(as), visibilizando la importancia de este tipo de mercancías y consumos en la configuración de la cultura nacional.

El libro recorre distintos períodos de la primera mitad del siglo $\mathrm{XX}$, reconociendo las especificidades históricas y locales que influyeron en la creación de determinados tipos de películas, y evidenciando la importancia que los mercados locales tuvieron en el contenido, la forma y la difusión del cine norteamericano. Purcell evidencia la no-neutralidad de la industria cultural hollywoodense en el contexto de una cruzada más extensa abocada a expandir el estilo de vida norteamericano a cada rincón del planeta, a través de las vinculaciones de los directivos de la industria del cine con el departamento de Estado de los Estados Unidos y con los embajadores a nivel latinoamericano. El libro constituye, así, una notable investigación que da cuenta de la importancia de la industria cultural en la configuración de la cultura chilena, sus vías de penetración y sus impactos. 


\section{Hollywood y su consolidación}

Cabe señalar que el cine no sólo fue patrimonio para los habitantes del centro del país, sino que se asentó cerca de las ciudades salitreras y en provincias del sur. El autor señala que el cine hollywoodense desplazó al cine europeo durante la década de 1910, y se impuso en el mercado chileno de forma acelerada y estable a través de la incorporación de géneros cinematográficos como el western, concitando el interés y el consumo más amplio del público latinoamericano. De esta forma, no es de extrañar que el $70 \%$ del cine que se estrenaba en el país en la década de 1940 proviniera de los Estados Unidos.

Durante los primeros años del siglo XX, no era predecible que el país experimentara un declive del cine europeo. Sin embargo, la baja en la producción cinematográfica a partir de la crisis producida por la I Guerra Mundial, la expansión decidida e intencionada del cine norteamericano con apoyo del departamento de Estado, y las distintas estrategias de venta en bloque que obligaban a los dueños de los cines a transmitir sus películas, fueron condiciones que facilitaron que el cine hollywoodense se instalara como el favorito para la población chilena.

Lo más llamativo de esta penetración fue el proceso de norteamericanización que ocurrió en Chile, fenómeno cultural que se evidenció en las crónicas de revistas e informes. De esta forma, el cine se transformó en un medio privilegiado para transmitir el estilo de vida estadounidense, y mostrárselo como deseable a una sociedad cada vez más abierta al consumo. No es de extrañar, por tanto, que una serie de productos fueran consolidándose como parte esencial de la vida de los(as) chilenos(as), y que, tal como podemos observar en la actualidad, hayan trascendido y perdurado en el tiempo hasta los días de hoy.

Para que el cine se introdujera sin mayores rechazos, fue preciso conocer los gustos locales a la vez que entender y utilizar la censura, estrategias que promovieron la consolidación de Hollywood en los distintos países latinoamericanos. En este escenario, en la primera y segunda década (1910-1920) se estudió sistemáticamente, a partir de cuestionarios y cartas que los propios embajadores enviaban a Estados Unidos, el tipo de consumo de los(as) chilenos(as), sus gustos, el tipo de público predominante, los espacios de exhibición, etc. En la tercera y cuarta década (1930-1940), y en el contexto de la II Guerra Mundial, el tipo de interés se volcó más en las ofensas y en la manipulación, de manera de 
procurar que el cine norteamericano tuviera amplia cabida y aceptación por parte de una sociedad que debía aliarse con Norteamérica y no con Alemania. En este punto, es interesante recalcar la cantidad de fuentes que son trabajadas por el autor para comprender este fenómeno: desde artículos en revistas hasta sesiones del senado donde se exponían los límites que el cine norteamericano debía franquear, se recolectaron materiales que se constituyeron en insumos valiosos para moldear la producción cinematográfica en Estados Unidos.

Purcell examina, además, la puesta en práctica y la influencia del sistema de estrellas como uno de los mecanismos de publicidad destacados que desplegó el cine hollywoodense para instalarse y consolidarse en tierras chilenas. A partir del estrellato, el cine norteamericano rápidamente desplazó al cine europeo: las celebridades, su fama y sus películas se vinculaban con un conjunto de objetos de consumo, tales como revistas, crónicas, álbumes, etc., a partir de los cuales se expandía el comercio y las ganancias norteamericanas en el país. A su vez, las visitas a Chile de diversos actores permitieron una cercanía mayor del público con la magia del cine. Estas estrategias fueron fríamente calculadas por la industria del cine norteamericano, que exigía a sus personalidades estos viajes publicitarios como parte de sus labores y deberes de contrato. En el país se registró la llegada de actores como Art Acord en 1922 y Walt Disney en 1941, lo que permite comprender la extensión temporal de este proceso de fijación de referentes norteamericanos en la cultura chilena. Las visitas, las historias y las dedicatorias que actores y actrices entregaban -en vivo o por correo- a sus admiradores(as) chilenos(as), tenían la clara intención de promover el cine no como una acción individual, sino como parte de una demanda colectiva que redundaba en la adopción y la homogeneización de identidades de consumo bien definidas.

En términos globales, el libro también indaga en el cine como propaganda de guerra. Si la I Guerra Mundial había permitido la apertura del cine norteamericano a América Latina, la ll Guerra Mundial se presentaba como un escenario donde el cine funcionó con claros intereses ideológicos tanto en territorio norteamericano como latinoamericano. A partir de ello, las relaciones diplomáticas de Estados Unidos se vieron sensibilizadas por el cine y los imaginarios aportados por las películas, donde, por ejemplo, se realizaban analogías permanentes sobre el conflicto bélico, de manera de resaltar los valores de libertad y vincularlos con Norteamérica. Como se ha mencionado, esta estrategia propagandística 
estuvo apoyada por el Departamento de Estado norteamericano, con el propósito de promover las buenas relaciones con el continente en medio de una crisis global, y reportar, por cierto, ganancias tanto materiales como simbólicas. Así, el financiamiento de estudios cinematográficos se entregaba con la condición de producir películas que permitieran posicionar positivamente la imagen de Estados Unidos, y que, a su vez, promocionaran y desmitificaran ciertas imágenes sobre América Latina que los norteamericanos mantenían. Con ello, por ejemplo, la promoción de películas sobre Chile o personajes chilenos generó una alta expectación en el público local, aunque no necesariamente llegaran a producirse dichas cintas o éstas alcanzaran fama mundial.

\section{El séptimo arte y la cultura de masas durante el siglo $X X$}

La reseña de este libro permite evidenciar el impacto que, en términos concretos y subjetivos, tuvo el cine hollywoodense en la sociedad chilena. En este sentido, las industrias culturales influenciadas por los patrones de modernización norteamericanos fueron las que moldearon las imágenes de lo aceptable, deseable y positivo que los(as) chilenos(as) aspirarían para sí. De este modo, las representaciones cinematográficas -las cuales iban desde el ideal de la fama hasta la obtención de ciertas posesiones 0 atributos- fueron consumiéndose masiva y progresivamente, transformándose en poderosas fuentes de información que tensionaron los convencionalismos de la población chilena. Con el paso del tiempo, dichas representaciones fueron enraizándose en la audiencia, modificando la identidad cultural del país desde principios del siglo XX hasta la actualidad. 
